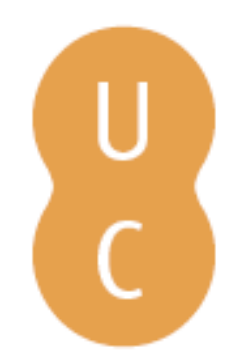

\title{
pommalina
}

\section{Medéia em Ovídio: a magia como metamorfose}

Autor(es): $\quad$ Suárez de la Torre, Emilio

Publicado por: Imprensa da Universidade de Coimbra; Universidad de Valladolid

URL

persistente: URI:http://hdl.handle.net/10316.2/32301

DOI: $\quad$ DOI:http://dx.doi.org/10.14195/978-989-26-0472-5_5

Accessed : $\quad$ 26-Apr-2023 13:08:27

A navegação consulta e descarregamento dos títulos inseridos nas Bibliotecas Digitais UC Digitalis, UC Pombalina e UC Impactum, pressupõem a aceitação plena e sem reservas dos Termos e Condições de Uso destas Bibliotecas Digitais, disponíveis em https://digitalis.uc.pt/pt-pt/termos.

Conforme exposto nos referidos Termos e Condições de Uso, o descarregamento de títulos de acesso restrito requer uma licença válida de autorização devendo o utilizador aceder ao(s) documento(s) a partir de um endereço de IP da instituição detentora da supramencionada licença.

Ao utilizador é apenas permitido o descarregamento para uso pessoal, pelo que o emprego do(s) título(s) descarregado(s) para outro fim, designadamente comercial, carece de autorização do respetivo autor ou editor da obra.

Na medida em que todas as obras da UC Digitalis se encontram protegidas pelo Código do Direito de Autor e Direitos Conexos e demais legislação aplicável, toda a cópia, parcial ou total, deste documento, nos casos em que é legalmente admitida, deverá conter ou fazer-se acompanhar por este aviso.

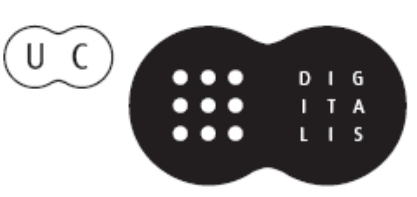


Emilio Suárez de la Torre

Maria do Céu Fialho

(Coordinadores)

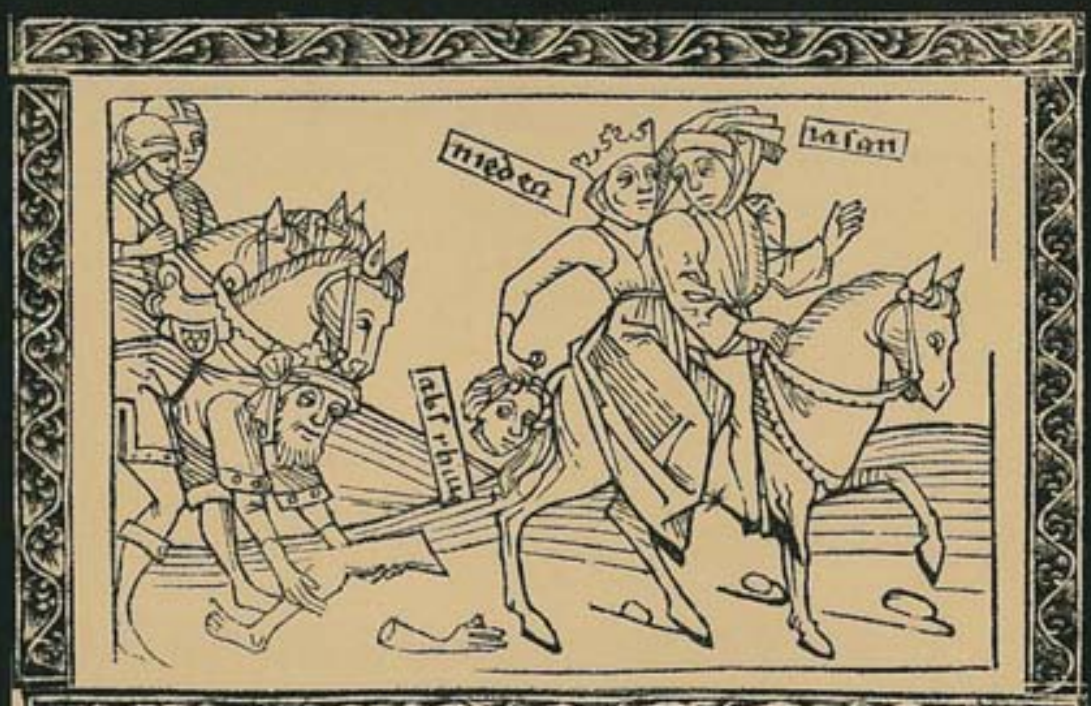

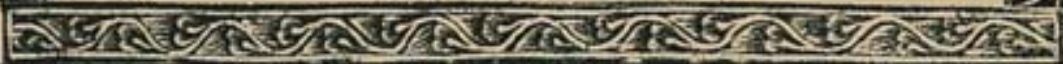

\section{BAJO EL SIGNO DE MEDEA}

\section{SOB O SIGNO DE MEDÉIA}




\title{
Medéia em Ovídio: A magia como metamorfose
}

\author{
EMILIO SUÁREZ DE LA TORRE \\ Universidade de Valladolid
}

\section{I}

As Metamorfoses de Ovídio é muito mais do que uma obra poéticomitográfica. É, com certeza, uma excepcional composiçáo poética e a mais impressionante recopilaçáo de relatos mitológicos com coerência temática que jamais foi escrita. No entanto, em um patamar năo menos importante, trata-se de uma grande obra filosófica de exaltaçâo da grandeza de Roma e, sobretudo, da grandeza da poesia e do poder da palavra poética; mesmo que esta afirmaçāo possa parecer muito surpreendente.

Começarei pela perspectiva filosófica, o que exige a adopçāo de um ponto de vista geral com relaçăo ao pensamento da Antiguidade. As ideias de mudança, evoluçăo e mutaçáo ocuparam entre os Antigos um papel central na discussăo filosófica. A crença na possibilidade de que um ser determinado transforme-se noutro ser (em todos os âmbitos da sua existencia e de forma absoluta) implica que esta possibilidade esteja sustentada por outra serie de crenças que englobam:

(a) A aceitação de que a matéria possa sofrer uma transformaçáo a partir da sua própria composição ou natureza, sem a necessidade de lançar máo dos conceitos de prodígio ou milagre (mesmo que na sociedade em questáo haja de fato esta interpretaçăo simultáneamente). Desde os mais remotos vislumbres filosóficos (especialmente nos começos, quando a matéria é practicamente tratada como um ser vivo) assistimos duas formas de explicar a mudança (e, de alguma forma, numa perspectiva temporal, a 
evolução), que $\mathrm{H}$. Bergtson ${ }^{(1)}$ reduzia, de forma muito útil, a duas propostas: a dinamista e a mecanicista ${ }^{(2)}$.

(b) A possibilidade, no seu caso (quando existe um dualismo claro - que nem sempre ocorre- entre o anímico e o corpóreo), de que ocorra uma metempsicose simultânea ou metensomatose.

(c) A crença na inter-relação entre os elementos de forma radical. Esta ideia encontrou no plano filosófico duas manifestaçōes aparentemente díspares, porém de grande influência: o dinamismo radical de Heráclito e a crença num continuum somente o superficial e aparentemente modificado de Parmênides.

(d) A concepçāo materialista dos processos psicológicos, afectivos e similares, com grande enraizamento no plano lingǘstico.

(e) A aceitação da possibilidade de inter-relaçăo entre realidades materiais muito díspares, por efeitos analógicos e de influências físicas directas, mesmo que as entidades implicadas pertençam a classes muito distintas: cf., por exemplo, o princípio de similia similibus, a crença no poder directo modificador da palavra $(\dot{\epsilon} \pi \varphi \hat{\delta} \tilde{\eta})$, etc.

(f) O conceito evolutivo do universo é de uma especial importância. O modelo "do caos ao cosmos" contém en si uma inquietante ameaça: Como garante-se a consecução de uma ordem definitiva? Devido ao visível potencial de mutabilidade existente em todo o tipo de coisas, a alteraçăo cósmica é sempre uma ameaçante possibilidade. A relaçăo entre Microcosmos e Macrocosmos tem neste caso especial influência: por isso um prodigium produz um alarme social imediato.

A enumeraçāo de aspectos que, segundo o meu ponto de vista, tem alguma relaçáo com a aceitaçáo da metamorfose poderia ser ampliada, mas creio que os que foram descritos já sẫo suficientemente representativos. $\mathrm{O}$ seguinte procedimento consiste em demostrar que estes têm, pelo menos alguns deles, algo que ver com uma composição da envergadura de Metamorphoseon libri $X V$.

Essa impressionante obra poética, apesar da sua riqueza de conteúdo, possui uma estrutura relativamente simples, e seguindo-a destacarei só

(1) Nos seus Cours de Philosophie, que foram recuperados e editados por Henri Hude: H. Bergson, Cours sur la philosophie grecque, Paris, PUF, 2000 (Bergson, Cours IV, sér. Épiméthée).

(2) Ele explicava-o com o exemplo da luz que passa através do cristal vermelho: $\mathrm{cf}$. op. cit., pp. 62-63. 
alguns aspectos relevantes para a minha argumentaçăo ${ }^{(3)}$ (sem pretensóes, muito menos de originalidade). Começa-se com um prefácio, breve mas substancial (1-4), no qual o poeta proclama a sua intençáo pessoal de empreender uma obra ${ }^{(4)}$ na qual estejam contidas "as mudanças de formas em novos e sucessivos corpos", pede a inspiraçăo dos deuses (que contribuiram para essas mutaçōes) e expōe o seu desejo de que o poema abranja desde a origem absoluta do mundo até a sua própria época.

In noua fert animus mutatas dicere formas corpora; di, coeptis (nam toos mutastis et illas) adspirate meis primaque ab origine mundi ad mea perpetuum deducite tempora carmen!

E, de facto, será assim. O carmen começa com a cosmogonia e termina com a exaltação da descendencia de Júlio César, a grandeza de Roma e a proclamaçâo da própria glória imperecível de Ovídio na mais pura tradição da poesia antiga:

Ore legar populi perque omnia saecula fama, siquid habent ueri uatum praesagia, uiuam.

A abertura e o encerramento da obra falam por si: o universo passou do caos primordial a uma nova ordem, que há-de ser estável, de Roma. Essa estabilidade está garantida pela poesia. Ovídio vai mais além do exegi monumentum aere perennius:

Iamque opus exegi, quod nec Iouis ira nec ignis nec poterit ferrum nec edax abolere uetustas.

O poema, incólume, é uma garantia de sobrevivência da ordem, é algo mais do que um carmen magicum, porque năo somente explica o sobrevir do universo, mas sim sanciona o seu equilibrio definitivo.

(3) Em von Albrecht (19942) 735-737 pode encontrar-se um útil esquema da obra, com especial e aguda insistência nos fundamentos que dăo coerência à estruturaçăo. A técnica ovidiana para conseguir essa coerência está bem analizada em Crabbe, $A N R W I I$ 31, 4, 22742327 , com referências bibliográficas. É uma exposiçăo mais completa e convincente que outras, como as de Ludwig (1965:excessivamente simplificadora neste aspecto); Otis (1966) 45-90 (que é mais temática que formal e também abrange grandes unidades) ou Coleman, (1971). Cf. Para além de Boillat (1976).

(4) Com novedades importantes conscientemente destacadas: cf. Mensching (1969) com respeito à sua postura subjacente quanto ao "prólogo dos Telquines" e o conceito

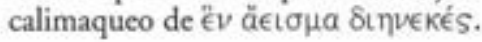


Não se chega a esta conclusão, naturalmente, somente lendo os dois primeiros e últimos versos, mais ao contrário, a partir da informaçāo implícita na estrutura geral. O componente filosófico é especialmente notável no início (explicaçăo das origens, com provável doutrina estoica, mas de ascendencia platônica, no livro I) e ao final (doutrina pitagórica no livro $\mathrm{XV}{ }^{(5)}$ ). $\mathrm{O}$ universo nas suas origens era pura metamorfose (cf. v. 17, nulli sua forma manebat $)^{(6)}$, confusāo e massa amorfa em contínua mutaçáo, que sofreu a sua primeira transformaçăo equilibrada graças a um Deus "criador" inominado (32 quisquis fuit ille deorum; cf. 57 mundi fabricator; 79 ille opifex rerum). De facto as sucessivas metamorfoses que compōem a obra inteira nẩo sāo mais que a prolongaçāo do processo até alcançar a consolidação definitiva de todas as realidades do universo. $\mathrm{O}$ mito das Idades (I 89-150) conduz-nos ao período e nova ordem de Júpiter, mas, a diferença de Hesíodo $(O p$. ...) a concepção de Ovídio é optimista e progressista. A partir deste momento, o livro I (e parcialmente o II) vão pôr ante os nossos olhos o processo de consecuçăo dessa nova ordem, por cima de diversos obstáculos e mutaçōes, que não serấo somente individuais. É o caso da vitória sobre os Gigantes (151-162), o castigo e a extinçẫo do género humano criminal e anómalo, representado por Lycaon (163-252) e o castigo do dilúvio (253-312), com o esperançoso resultado da descendência semeada por Deucalión e Pirra (313-415), uma mutaçăo decisiva, porquanto estabelece uma continuidade entre o mundo mineral e o género humano:

Inde genus durum sumus experiensque laborum et documenta damus qua simus origine nati. (414-415)

Ao mesmo tempo, o lama causada pela chuva converte-se em nova fonte geradora de vida, de maneira que o processo de criação consolida-se

(5) Cf. Lafaye, 1904 (reimpr. 1971) 157 ss., quem sugere, com importantes argumentos, que sua fonte principal neste aspecto pode ser Varráo e a paradoxografia, sem esquecer o papel de Posidonio quanto ao estoicismo. Ideias essenciais para a compreensão da relaçăo entre mito, pensamento filosófico e realidade coetânea nesta obra de Ovídio encontram-se em von Albrecht ANRWII 31,4, 2328-2342.

(6) Pace Schmidt (1991) 15-16, quem se opṓe a que a cosmogonia seja considerada metamorfose, já que este conceito deveria limitar-se a mudança de "forma a forma", enquanto que aqui estariamos diante duma simples cosmologia narrativa, na que se dota de forma à matéria. Porém, năo encontro de maneira geral impróprio assimilar os processos desde o ponto de vista das concepçóes que reflete o poema (conforme explico mais adiante). Cf. Bömer (1969) I, 12 (comentário a ad mutatas dicere formas): "mutare gehört zur Terminologie der Metamorphose, die Kosmogonie ist gleichzeitig die erste Metamorphose, wahrscheinlich eine Konzeption Ovids" (e cf. p. 14 o comentário à expressáo perpetutum carmen). Ao contrário, partilho plenamente com Schmidt a apreciação da importância do elemento psicológicoantropológico na obra, sempre e quando năo se considere o "factor" decisivo e omniexplicativo. 
com a inter-relaçāo de todos os elementos. Posteriormente, introduz relatos que protagonizados pelos deuses fiadores da nova ordem (na evoluçăo da humanidade e na própria Roma coetânea) como săo Apolo (I 416-567) e, sobretudo, Júpiter (desde I 568): a sua descendência fora do continente europeu recorda-se desde o final do livro I, para retornar (precisamente com o mito de Europa) ao final do livro II. Ao começo deste mesmo livro o próprio Júpiter deve solucionar outro indício de grande conflito universal (uma nova ameaça à ordem conseguida) protagonizado por Faetonte e a sua desditosa conduçăo do carro solar.

A partir daqui serăo os "grandes temas" ou fios condutores estruturais, junto com as unidades de transiçăo, as contínuas referencias cruzadas e os esquemas repetitivos. Destacamos a presença das tradiçōes tebanas e do dionisismo (directa ou indirectamente) nos livros III e IV, as aventuras de Perseo nos livros IV-V ou os castigos divinos (de novo Apolo) e o papel de Minerva no livro V, que sirve de algum modo de prelúdio ao progressivo peso de Atenas e sua mitologia nos livros VI-VIII, sem esquecer-nos do espaço dedicado pelo poeta a Hércules no IX. A presença de Orfeo e seu canto (como assinala-se com frequência, uma das diversas representaçōes do artista e suas tribulaçōes) preenche o livro X e parte do XI, que dá lugar ao tema de Tróia. Ou seja, pouco a pouco, o poeta aproxima-nos da tradiçăo mitológica que constitui o pano de fundo da própria ascendência dos fundadores de Roma e da família imperial. A mitologia pré-troiana, Tróia e os temas dos antigos nostoi, com a chegada ao Lacio, ocupam dos livros XI ao XIV, que já introduz-nos nas tradiçóes mais puramente romanas: cf. Alba Longa, Pomona e Vertumno ou Rómulo e Hersília.

Encerra-se assim, no livro XV, o círculo aberto ao começo. A longa exposição das doutrinas pitagóricas aprendidas por Numa está cheia de referências, de evocaçōes léxicas e conceituais, de numerosos episódios anteriores (e nāo somente do tema do livro I). Todavia, destaca a longa reflexão sobre o conceito de mutatio (porque omnia mutantur, v. 164), com o definitivo fundamento filosófico da ideia central do poema. Uma mudança que afeta o individuo e os demais seres, um processo que afeta o universo sem cessar, à realidade material e o tempo (183-185):

Tempora sic fugiunt pariter pariterque sequuntur

Et noua sunt semper; nam quod fuit ante, relictum est

Fitque, quod haud fuerat, momentaque cuncta nouatur.

Mas essa mesma mutação é a garantia de eternidade (nec perit in toto quicquam, mihi credite, mundo, v. 241) e, em nenhum caso, de perda de 
identidade: a poesia sustenta a explicaçăo imperecível da realidade permanente, graças à arte imortal de Ovídio ${ }^{(7)}$.

\section{II}

Passemos agora do quadro geral ao imediato, em cujo inscreve-se o relato de Medéia. Trata-se ${ }^{(8)}$ da sexta "grande secçâa", praticamente o centro de toda a obra, que englobaria, aproximadamente, desde a metade do livro VI (412) até o início del livro IX, no qual começa a mitologia de Hércules. Em Ovídio é importante, como já citamos acima, a relação de simetria entre as partes do conjunto, mas năo menos importante do que a relaçáo existente (com paralelismo, ecos e evocaçōes constantes) entre os relatos próximos, como ocorre precisamente nestes livros ${ }^{(9)}$.

A citada secção inicia-se com o trágico ${ }^{(10)}$ mito de Tereo, Procne e Filomela, cuja tipologia não é muito distinta (grosso modo) da encontrada em Medéia ${ }^{(11)}$. Ao menos Ovídio busca a inter-relaçăo. Em ambos casos o fogo de uma paixāo irrefreável desencadeia os acontecimentos ${ }^{(12)} \mathrm{e}$ (mesmo que narrativamente mais condensado no episodio de Procne) a vingança ao final recai sobre a descendência dos protagonistas. No restante do livro VI relata-se outra paixâo irrefreável, a de Bóreas por Oritia, cuja descendência alada (Calais e Zetes) serve de transiçăo à façanha dos Argonautas que abre o livro VII.

O livro VIII tem um esquema claramente tripartido. Inicia-se o primeiro bloco (enlaçando-o com o final "minóico-ateniense" do VII ${ }^{(13)}$ )

(7) A relaçăo entre visăo filosófico-cósmica, estrutura e relato ovidiano tem sido objecto de atenção por diversos autores. Veja-se, por exemplo, Solodow (1988), Myers (1994) e Tissol (1997). Também há observaçôes a respeito em Galinsky (1975).

(8) Conforme a divisão de von Albrecht, supra citada.

(9) Nāo há que esquecer-se também, no que a Medéia se refere, que Ovidio recorreu por três vezes a este mito, desde pontos de vista e em géneros muito diferentes, mas com perspectivas complementárias. A Heroida VI, a epístola elegíaca de Medéia a Jasāo, situa-se em Corinto, nas vésperas do novo casamento de Jasáo, episódios que em Metamorfoses estão muito sintetizados, como logo veremos. Se, como se supôs, a Medéia de Séneca tinha alguma influência da tragédia homónima escrita por Ovídio, da que tão somente há uma linha, estariamos diante duma dramatizaçáo dos trágicos acontecimentos que se pressagiam na Heroida VI.

(10) Já desde o seu início o casamento era infausto, como se sublinha com a presença das Euménides (430).

(11) Para o paralelismo e diferenças entre Medéia e os casos de Procne, Escila, Procris e Oritia, vid. as acertadas reflexōes de Newlands (1997).

(12) A beleza de Procne acende a paixăo de Tereo de forma similar ao que lhe acontece a Medéia com Jasáo: cf. 447-460 - 7-89 (sobretudo 77-89).

(13) Cf. infra. 
com outro exemplo de amor febril, tipologicamente ainda mais próximo do caso de Medéia (mesmo que deliberadamente contrastado também por Ovídio). Trata-se da paixāo de Cila, filha do rei Niso, por Minos, o inimigo e traidor (juntamente com o seu pai) da sua pátria. As aventuras de Teseo e o mito de Dédalo e Ícaro (paralelo ao de Faetonte no livro II) dão lugar ao segundo bloco no qual desenvolve-se o mito de Meléagro, onde novamente uma máe póe termo à vida do seu próprio filho. Um paralelo estructural interessante entre o livro VIII e o VII é o facto de que a parte final de ambos correspondem-se com os relatos que ocorrem em um banquete ou reuniẩo colectiva similar (neste caso, nas moradas do Aqueloo), que serve de pano de fundo às diversas narraçōes. Em ambos casos com heróis atenienses presentes (Céfalo e Teseo, este último funcionando como 'link' de quase todos estes relatos). Por último, o terceiro bloco apresenta-nos dois modelos contrastados de conduta em relaçáo aos deuses: o positivo de Filemon e Baucis e o negativo de Erisicton, cuja "proteica" filha Mestra protagoniza a mençăo que encerra o livro. A última parte da secçáo corresponde, já no livro IX (1-95), ao relato de Aqueloo sobre a sua rivalidade com Hércules pelo amor de Dejanira, o que explica a perda de um dos seus $\operatorname{cornos}^{(14)}$.

Este é pois, o quadro do livro VII, que se desenvolve entre a façanha dos Argonautas e a hostilidade entre Ática e Creta. A sua estrutura fundamental é bipartida, com uma primeira parte protagonizada por Medéia (até o verso 424) e uma segunda com os temas que afectam a Atenas e a Egina, o que também pode levar-nos, como assinala Crabbe ${ }^{(15)}$, a apreciar uma segunda estrutura em tríptico, com Medéia, Teseo-Atenas e Egina como referentes. $\mathrm{Na}$ realidade, Teseo será o fio condutor de diversos relatos. Não menos variada é a técnica narrativa, já que assistimos uma notável exibiçăo do relato descritivo, mais moroso, com monólogos e diálogos intercalados (predominantes na primera parte, cf. 7-349), combinado com descriçōes mais variadas e rápidas (cf. 350-424) ou com o recurso do "relato dentro do relato" (como os de Eaco e Céfalo) por ocasião do banquete de recepção ( 490 ao final), entre os quais, por sua vez, apresentam traços distintivos: entre a orientaçāo histórico-mítica (quase "refundacional") da narraçăo de Eaco e a novela amorosa (com tantos vestígios assumidos posteriormente pelo género) de Céfalo e Procris, narrada por ele mesmo. Por sua vez, a parte

(14) Por seguir com série de paralelos que vão entrelaçando esta obra, recordemos que no libro IX volta a aparecer o assunto do rejuvenescimento, protagonizado por Yolao (397417).

(15) Cf. seu esquema em $A N R W$ II 31, 4, 2274-2327. 
de Medéia é subdivisível em quatro unidades muito nítidas: (A) $\mathrm{O}$ apaixonamento e a ajuda de Medéia a Jasão, juntamente com a façanha deste (7-158) ${ }^{(16)}$; (B) O rejuvenescimento de Éson (159-293); (C) A morte de Pélias (296-349) y (D) A viagem de Medéia à Ática e a tentativa de assassinato do Teseo (350-424).

\section{III}

Após termos precisados os traços estruturais, veremos agora as características que o mito de Medéia apresenta nesta versăo ovidiana, sobretudo no quadro duma obra centrada na metamorfose ${ }^{(17)}$. As quatro partes que se distinguem até o verso 424 têm um denominador comum que pode ser resumido na palavra mudança, já seja interna, externa ou de aparência e, por último, o movimento ou mudança de localizaçăo. Ainda assim, faz-se mister destacar o papel central que desempenha em tudo isso o facto de que Medéia tenha poderes mágicos. Todos estes factos prodigiosos produzem-se em redor da magia, que Ovídio apresenta como inquietante poder omnímodo desestabilizador e daninho. $\mathrm{Na}$ obra ovidiana năo só produz-se um claro contraste, como viu o Segal ${ }^{(18)}$, entre a magia negra de Medéia (e Circe) e a "branca" de Canente, mas além disso, no meu juizo, subjaze uma valoraçāo contrastada entre os poderes terríveis e destrutores da magia negra e, em concreto, do carmen utilizado dessa forma e o carmen benéfico e ordenador do poeta: entre o encantamento de Medéia e o de Orfeo há um abismo, que é como dizer entre o carmen que usurpa os poderes metamórficos e o que os reconduz pela via da perpetuidade e imortalizaçăo ${ }^{(19)}$.

(A). A primeira alteraçâo é padecida pela própia Medéia, quem concipit ualidos ignes (9) e náo pode vencer o furor (11) com a razăo. A experiência da paixăo amorosa vai surpreendê-la e alterá-la

(16) Ao mesmo tempo, há aqui duas partes claras: (a) enamoramento e diálogo com Jasăo (7-99) e (b) provas que este supera (100-158).

(17) Das versốes existentes do mito, a selecção temática de Ovídio aproxima-o logicamente ao modelo de Apolonio de Rodas, ainda que as diferenças săo também notáveis. Ê muito importante que Ovidio proponha a colaboração de Medéia com Jasáo como decisĭo própria, fruto da paixão amorosa, sem que existam outros condicionamentos. Em Apolonio, por exemplo, o recurso a Medéia é sugerido pelo seu próprio irmäo Argos (cf. III 523-539), ainda que, obviamente o elemento passional é fundamental.

(18) Segal (2000 y 2001-2002).

(19) Veja-se a situaçăo de Medéia, entre o canto das Musas do livro V e o de Orfeo do $X$. Erbse (2003) viu bem a diferença entre a metamorfose causada pelos deuses e a que provoca Medéia. 
radicalmente ${ }^{(20)}$ : é uma noua uis que desconhece. Esta primeira Medéia ${ }^{(21)}$ do livro VII ainda não é a maga na que se transforma imediatamente, e sim uma simples jovem invadida por um fogo amoroso irrefreável. A beleza de Jasăo comoveu (mouit) a suas entranhas (28) e ela está convencida de que tem um deus dentro de si (55). O seu espírito debate-se e aparentemente toma uma decisão (nấo ceder ao amor) que dura até o momento em que esta vê o herói e, entăo, a "extinta chama volta a brilhar" (77). A paixão de Medéia prende-se de forma definitiva precisamente no bosque de Hécate, espaço tẩo importante quanto a deusa ${ }^{(22)}$, em todos os processos subsequentes ${ }^{(23)}$. De alguna forma Medéia está presa à sua própia armadilha: Hécate triforme, deusa da magia, preside também a mutaçăo de Medéia. O juramento quádruplo de Jasăo, que implica a três divindades ${ }^{(24)}$. Hécate, o nume do bosque e o omnividente sol, avô de Medéia, além de (ironicamente) o êxito das acçōes futuras, sela de forma dramática o novo destino, táo terrível e cheio de mutaçōes, de ambos a partir desse encontro. Jasão recebe as cantatas herbas (98) que produzirāo os próximos prodígios ${ }^{(25)}$.

O primeiro grupo de alteraçóes mágicas produz-se, pois, nas provas que deverăo ser superadas por Jasăo (140-148): tantum medicamina possunt (116). O fogo nāo o afecta, os bois ficam mansos e os guerreiros nascidos do plantio dos uipereos dentes (agora resto anómalo do que foi o repovoamento pós-diluviano) matam-se entre si, sem ferir o herói. Esta semeadura (que se produz depois de orvalhar a terra com o ualido ueneno [123]) encerra uma metamorfose descrita nos termos que associam a terra e o corpo humano através de uma expressiva semelhança (125-130). A contemplaçáo dos ameaçadores guerreiros produz temor (nova alteraçâo interior) à própria Medéia (ipsa quoque extimuit), quem entoa um carmen auxiliare (137-138). Na continuaçâo, produz-se o prodígio que precipita a fuga para Iolco: o gramen suci e a tríplice fórmula mágica (uerbaque ter dixit) adormecem o dragáo e o velocino de ouro é conquistado (152-158).

(20) Pïndaro tinha-o explicado precisamente pelo efeito da magia do iu $\xi \xi(P, 4,213$ 219). Aqui Ovídio está mais próximo do modelo de Apolonio de Rodas (cf. Arg. III 616 ss.).

(21) Cf. Newlands (1997).

(22) Sua parente; $c f$. Newlands (1997) 184.

(23) Neste caso mantem-se a situação de Apolonio de Rodas, só que neste poeta o encontro no santuário de Hécate está perfeitamente delimitado pela preparaçảo concertada do encontro e por suas consequências; cf. III 828-1172.

(24) O três é decisivo na obra.

(25) Esta é otra das diferenças com Apolonio de Rodas, em cujo relato só se menciona o uso da planta prodigiosa Prometheion, que cresceu com o i $\chi \omega$ w derramado das entranhas de Prometeu; cf. Arg. III 845 ss. 
(B). Quando chegam a Iolco, o Jasão, disposto a ceder parte dos seus próprios anos, pede para a Medéia o rejuvenescimento paterno. Mas esta recuza-se a fazê-lo e dispóe-se a levar a cabo um rejuvenescimento radical mediante as suas próprias artes. Ovídio procede com uma detalhadíssima descriçáo dos passos seguidos pela maga bárbara, com especial cuidado na selecçẩo dos elementos. $\mathrm{O}$ resultado disso traduziu-se numa das mais interessantes descripçóes de um procedimento mágico na literatura. A Medéia aguarda a lua cheia e distancia-se da casa com os pés descalços e os cabelos soltos, através do silêncio da noite ${ }^{(26)}$, até o bosque mais próximo. Empapa três vezes os seus cabelos no rio, grita três vezes e começa, ajoelhada no chăo, a sua invocaçăo. Nesta passagem observamos uma característica de especial relevancia: é uma invocaçáo que afecta todos os elementos do universo, os seres animados e inanimados: nox, luna, astra, Hécate (aqui triceps), Tellus, assim como

auraeque et uenti montesque amnesque lacusque,

dique omnes nemorum dique omnes noctis, adeste!

A relaçáo de invocados corresponde-se rigorosamente com todas as esferas de poder da Medéia, que os detalha à continuação, relembrando (no esquema habitual da súplica) a ajuda anteriormente recebida dos invocados: assim, ela relata o efeito da sua magia sobre amnes, freta, nubila, uentos, uiperas, saxa, terra, siluas, montes, manes, Luna, o currus do Sol e a Aurora. Esta concepçẩo universal do poder mágico corresponde-se a uma concepção da magia como criação alternativa ou (como desprende-se do conjunto) incluso como uma anti-criaçăo. Ao mesmo tempo que pốe em relevo a implicaçáo de todas as esferas ou aspectos do universo nos processos mágicos, nos quais é fundamental a inter-relação de elementos. Isso também contribui para a sua aproximação ao processo de metamorfose. Neste sentido, tampouco carece de significação a viagem que, na sequência, empreende a Medéia em busca de ervas, já que tem lugar por montes e vales (Tempe, Osa e Pelio, Otris, Pindo e Olimpo); rios (Erídano, Anfrisio, Enipeo, Peneo, Esperqueo), uma lagoa (litora Boebes) e um ilha (Eubea): uma variedade de acidentes geográficos em consonância com o anterior.

O Ovídio presta especial atenção à descripçâo do ritual mágico propriamente dito, que a Medéia realiza depois do seu regresso (do que sublinha a abstençâo de contacto sexual, primeiro elemento ritual a ter em

(26) Observe-se de novo o papel do três: ter aberant noctes (179); homines uolucresque ferasque (185); silent frondes; silet humidus aer. Sidera sola micant (187-8). 
conta). Em primeiro lugar, procede à placatio dos deuses envolvidos no processo. Em uma adaptaçáo ad hoc do procedimento, a Medéia começa erigindo um altar para Hécate e outro para Iuventa, já que se trata de conseguir que a senectus retorne in florem. Na continuaçăo, deve conseguir o favor dos di inferi (os terrena numina, além de Plutâo e Prosérpina), para o qual, depois de escavar duas fossas, verte-lhes primeiro o sangue da ovelha preta que procede a degolar e, em seguida, o conteúdo de duas jarras, uma de mel e outra de leite, totalmente em consonância com o que conhecemos deste tipo de rituais ${ }^{(27)}$. Todo este processo é acompanhado da petiçăo aos deuses indicados.

Manda trazer o corpo doente de Éson, a quem adormece com um carmen, e, com uma fórmula de evocaçōes órficas, monet arcanis oculos remouere profanos (256). A Medéia é descrita agora como uma Bacante, que, com as tochas humedecidas nas fossas anteriormente descritas, circunda os altares, para proceder à lustratio do enfermo, que reveste o carácter acumulativo que se aprecia em todos os seus ritos. É uma purificaçăo com triplas aplicaçóes de fogo, água e enxofre. Ela deposita na água fervente os componentes do mágico medicamen, cuja variedade novamente vale a pena destacar. Aqui voltamos a encontrar representados todos os elementos da natureza, como si assistíssimos uma síntese universal, mas com aspectos particulares que dão uma orientaçẩo ominosa ao conjunto. Em primeiro lugar, raízes, sementes e sumos negros; depois, pedras do Oriente e areias deixadas pelo Oceano, junto com o orvalho congelado recolhido à luz da lua. A evocaçăo das mais estranhas formas $\mathrm{e}$ as obscuras metamorfoses podem ser vistas nas carnudas asas de vampiro e no focinho do licantropo. Seguida por uma escamosa pele de cobra d'água, o fígado de um corvo e a cabeza de uma gralha que tenha vivido nove geraçóes. Neste caso, pois, o elemento animal está representado pelos seres que, devido às suas singulares características, subentende-se que possuem uma especial longevidade, aparentemente motivada em alguns casos por metamorfoses totais ou parciais. Tudo isso junto com outros inumeráveis componentes nāo detalhados pelo poeta.

A Medéia nota que a mistura funciona: o ramo seco e velho da oliveira com a que a agita (omnia confudit summisque immiscuit ima, 278) reverdece e dá fruto instantaneamente e na terra onde foi esparramado o líquido brotam e nascem flores e ervas. Com isso procede a sua particular transfusāo: o talho no pescoço do anciāo faz correr o sangue que é

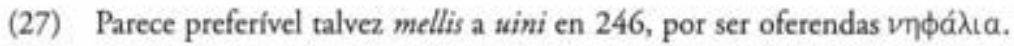


substituido pelo novo, tanto através da ferida como pela boca, alcançando o resultado esperado. Com elementos tradicionais de descripçōes literárias similares, Éson recupera a cor escura dos cabelos e dos pelos, a sua palidez e decrepitude desaparecem, juntamente com as rugas, e os seus membros luxuriant (292): ganhou uns quarenta anos. A conjunçáo de todos os elementos produziu o efeito esperado no microcosmo humano.

Ovídio introduz uma pausa antes de descrever o que será o "antiprodígio" ou versâo negativa destes poderes. Baco, que contemplou o assombroso prodígio (tanti miracula monstri, 294) recebe como don a mistura mágica para as suas nutrices: um dos muitos recursos alusivos às transformaçōes que Ovídio introduz com frequência (294-296). Só que nâo parece banal que o deus das bacantes (e a Medéia se tranformem por uns momentos em uma delas), o deus dos múltiplos rostos, o que se move entre a vida e a morte, que morre e renasce, que foi despedaçado e recomposto no mito órfico, seja quem se deixe ver por um instante e o que, frente à obrigada ausência dos espectadores, foi o privilegiado contemplador divino das acçōes mágicas.

(C). Depois dessa breve pausa Ovídio aborda o exemplo que ilustra a daninha perfídia da Medéia, a morte de Pélias, estabelecendo um buscado paralelo com o caso anterior para salientar as diferenças ${ }^{(28)}$. Para que nấo nos enganemos, Ovídio qualifica toda esta série de prodígios de doli (97) e à propria Medéia de callida (300). O primeiro contraste consiste em condensar muito mais a acçăo, mesmo sobre um esquema similar, no qual tudo é falso. Assim, para começar, finge ${ }^{(29)}$ a disputa com Jasáo. Para reforçar o seu engano, a Medéia, descrita agora como uenefica (316) realiza um prodigio real, o rejuvenescimento do carneiro mais velho do rebanho, que se transforma em borrego de leite ao ser submergido no recipiente que contém ualidos sucos (316) ou medicamina (317). O falso rejuvenescimento ocorrerá à noite (cf. a evocaçăo interna em quarta radiantia nocte micabant / sidera (325-6), mas desta vez há quem assiste a falsa transformaçăo e substituem a Medéia com uma faca na mão: săo as próprias filhas de Pélias, que executarāo (mesmo contrariando) o seu pai e querendo rejuvenescê-lo $(339-40)^{(30)}$ :

his, ut quaeque pia est hortatibus impia prima est et, ne sit scelerata, facit scelus...

(28) Jașio desaparece lentamente da cena. Tudo já é iniciativa de Medéia.

(29) (cf. odium falsum, 297; adsimulat 298; amicitiae mendacis imagine 301; dubitare uidetur 307; ficta grauitate 308; mais adiante será fallax Aeetias 326, etc.).

(30) Sobre a importância destes versos no conjunto vid. Frécaut (1989). 
A Medéia desta vez só emprega a sua capacidade mágica para o engano: é o último passo na transformação maligna progressiva da feiticeira. Somente empregou a mistura mágica para enganar o carneiro e agora o cantus ressoou só para adormecer a vítima. No entanto, o caldeirão nāo contém nada mais que água sem efeito algum (cf. imponit purum laticen et sine uiribus herbas 327). O último corte foi por ela evitado, do mesmo modo que a imersấo no inútil recipiente: a Medéia provocou o prodígio contrário ao anterior, a transformaçáo de Pélias em um cadáver sem sangue.

(D). O processo de degradaçăo da Medéia é imparável. A sua vida será uma sequência de atrocidades. Essa nova mudança vital, expresar-se-á novamente mediante a viagem aérea. O Ovídio utiliza este recurso para introduzir referências breves de outras diversas metamorfoses (passadas ou futuras), a partir dos lugares pelos quais a Medéia passa. $\mathrm{O}$ seu itinerário é ziguezagueante, talvez intencionadamente enlouquecedor, mesmo que fique claro o seu rumo pela Ásia menor e atrevés de Cos e Rodas, passando a seguir pela Grécia continental e o Peloponeso. A viagem é também temporária, já que damos um salto até os episódios de Corinto, que ficam resumidos em quatro versos (394-97) e que sintetizam o que Eurípides havia desenvolvido na sua Medéia, o que não impede a presença de elementos significativos. De novo evocam-se terríveis sucessos movidos pelos "venenos de Cólquide" (Colchis... uenenis 394): a nova esposa e o palácio inteiro abrasados, os filhos assassinados por ela mesma ${ }^{(31)}$. A Medéia chega a Atenas na sua carruagem de "titânicos dragōes", em um voo que serve de evocaçăo a outras três metamorfoses em aves, e é acolhida por Egeo. A brevidade desta nova mudança de localizaçẩo contribui para sublinhar o acelerado processo de monstruosa degeneraçáa que se observou. Na continuaçấ, o Ovidio póe em cena o Teseo com uma dos seus mais frequentes elos (iamque) ${ }^{(32)}$, de tal modo que, sem ter concluído a história da Medéia, a personagem que vai servir de enlace e fundamento dos siguintes relatos (também após a desapariçâo da Medéia) aparece com notável destaque.

A Medéia procede ao último dos seus crimes, desta vez falhado, para o qual năo se dá causa nenhuma, com um procedimento que merece ser sublinhado. Agora trata-se de um envenenamento, mas a substância

(31) A degeneraçắo moral é acentuada por Ovídio: cf. impius ensis (396), ultaque se male mater (397).

(32) O lexema aparece mais de cinquenta vezes em Metamorfoses, geralmente em momentos $\mathrm{em}$ que a narração ganha $\mathrm{em}$ intensidade e vivacidade. 
utilizada remete-nos mais uma vez a essa particular relaçăo dos componentes do universo que constitui o eixo central da actuaçăo mágica. $\mathrm{O}$ veneno é procedente das fauces de Cérbero (evoca-se a acção de Heracles), no entanto através de um processo de mutação que implica à terra mesma: as ervas empregadas na bebida medicinal procedem da solidificaçăo da espuma canina no solo.

O Teseo livra-se da morte quando o Egeo reconhece os signa impressos no punho da espada. O Ovídio sublinha que săo os signa sui generis. Ou seja, o reencontro de uma linhagem (decisivo no acontecer "histórico" sucessivo) produz-se graças ao incidente provocado por quem destruiu toda possibilidade de perpetuar uma estirpe (cf. ulta... male mater 397). Por último, a presença da Medéia conclui-se com a descriçẩo da sua última viagem. A Medéia realmente desvanece-se, desaparece do relato com um último voo (de novo effugit: cf. 307, 424). Mas essa desapariçāo é acompanhada, mais uma vez, do uso de umas artes mágicas nas quais o carmen poderoso e transformador encerra o ciclo da sua existência humana (effugit illa necem nebulis per carmina motis 424).

\section{IV}

A partir das idéias que acabamos de desenvolver e dos vestigios detectados no livro VII de a Metamorfose podemos chegar às seguintes conclusôes:

1. A posiçáo central do mito de Medéia no poema ovidiano obedece a razóes estruturais e conceptuais. Nessa dupla perspectiva estabelece-se constantes referências cruzadas com o entorno imediato do poema (paralelismo entre os mitos, personagens e situaçôes similares, ecos verbais) e com o conjunto da obra.

2. A consonância com o conjunto refere-se substancialmente ao conceito de mutatio considerado de modo geral. A complexa ilustraçăo do mesmo, dentro da presente obra, enlaça, nas passagens analizadas, com uma valoraçấo subjacente da magia e, ao mesmo tempo, da funçăo da palavra poética.

3. Com efeito, o conceito de mudança, sob a perspectiva ovidiana, tem uma triple dimensão: uma de carácter primordial para os começos do universo, outra de configuraçáo progressiva do universo e de todos os seus elementos e seres que o compōe; e uma terceira de mutaçăo constante desses mesmos componentes do universo. Isso sim, esta última năo é incompatível com um conceito de equilíbrio eterno, nâo somente pela sua 
origem divina ou natural, mas também porque esse carácter de equilíbrio eterno pode estar sustentado e reforçado pela voz do poeta; por sua vez desde duas dimensốes: o carmen philosophicum pitagórico e o poeticum (epicum) ovidiano ${ }^{(33)}$, que dota a realidade com uma estrutura verbalizada harmónica e com pretensóes de permanencia.

4. Frente a isto, o carmen magicum (e os poderes mágicos em geral) mostra uma capacidade de mutaçáo provocada fora da ordem universal e com possibilidades daninhas e criminais. $\mathrm{O}$ princípio de inter-relação dos elementos demonstra-se através da descriçâo da actividade mágica com todo luxo de detalhes. Apesar de a sua integração no domínio de Hécate, é evidente que está manifestadamente contrastado com a mudança executada por outros deuses (directamente) ou com o que se produz de modo natural, já que se orienta em direcção a uma forçada alteraçăo dos processos naturais ou em direcçảo a simples destruiçấo total.

5. A Medéia exemplifica de modo excepcional esta valoraçâo ovidiana e outros muitos conceitos. No âmbito pessoal, Ovídio esmera-se em apresentar-nos uma evolução da personagem baseada na alteração da sua própria personalidade e, talvez, no desenvolvimento negativo de algumas das suas características. É a descriçāo da evoluçăo de uma personagem feminina inquietante, cujas iniciativas sâo tăo radicais e anómalas como extranha é a sua própria situaçáo vital. A pacífica jovem surprendida pela força desconhecida do amor pổe de manifesto os seus poderes mágicos em funçăo desse mesmo amor. Por sua vez, o uso desses poderes mágicos evoluirāo em um sentido cada vez mais funesto e cruel $^{(34)}$, até chegar a falhada tentativa de assassinato do Teseo, convertida já na mais desarreigada das desarreigadas. O fracasso dessa última acção mágica assinala precisamente o desvanecimento da figura da Medéia do poema ovidiano.

6. Por último, a adaptação ovidiana do mito obriga a uma reflexăo sobre o status da Medéia. O Ovídio nấo a apresenta como uma divindade ${ }^{(35)}$, nem tampouco como uma mulher de entalhe meramente humano. É evidente que lhe otorga um status intermediário, quase demoníaco ${ }^{(36)}$, com elementos humanos e divinos ao mesmo tempo,

(33) Tendo em conta que o primeiro está inserido no segundo.

(34) Quanto mais negativo, o relato vai-se abreviando.

(35) Sobre o carácter divino de Medéia em suas origens (uma Medéia initiatrix) e o impacto do mesmo na evolução mítica cf. Graf (1997).

(36) Com o que, mutatis mutandis, recupera algo do que pôde ser um de seus aspectos primitivos, ainda que de diferente signo: $\mathrm{cf}$. Johnston (1997). 
porém com uma valoração negativa dos seus anormais poderes de feiticeira. Desta forma, pode-se explicar a particular evolução da sua figura neste livro VII, o que permite ao poeta fazer com que irrompa na acçāo como uma simples mulher apaixonada para desvanecer-se ao final, deixando implícita a possibilidade de uma existência de evoluçăo ${ }^{(37)}$ incerta.

\section{BIBLIOGRAFIA}

AlBRECHT, M. von: "Quellen- und Interpretationsprobleme in Ovids Metamorphosen: Eine Einführung, in Lafaye (1904, reimpr. 1971) V-XXXI.

- "Mythos und römische Realität in Ovids 'Metamorphosen"”, ANRWII 31,4, 2328-2342.

- Historia de la literatura romana (trad. esp. de D. Estefanía y A. Pociña de la edición de 1994²), Barcelona, Herder, 1997 (I-II).

Bessone, F.: P. Ovidii Nasonis Heroidum Epistula XII: Medea Iasoni, Firenze, Felice Le Monnier, 1997 (res. J.C. McKeown, BMCR 98.09.09).

BOMER, F.: P. Ovidius Naso Metamorphosen, Heidelberg 1969 (I-III).

Bolluat, M.: Les Métamorphoses d'Ovide. Thèmes majeurs et problèmes de composition, Bern/Frankfurt 1976.

Claus, J.J.; Johnston, S.I. (eds.): Medea, Essays on Medea in Myth, Literature, philosophy, and Art, Princeton, N.J., 1997.

Coleman: "Structure and Intention in the Metamorphoses", CQ N.S. 21 (1971) 461-477.

Coluins, D.: "Nature, Cause, and Agencyin Greek Magic", TAPhA 133 (2003) $17-49$.

CrabBe, A.: "Structure and Content in Ovid's 'Metamorphoses", ANRW II 31, 4, 2274-2327.

ERBSE, H.: "Beobachtungen über die funktion der Metamorphosen bei Ovid", Hermes 131 (2003) 323-349.

FrÉCAUt, J.-M.: "Une double antithèse oxymorique, clef d'un épisode des Métamorphoses d'Ovide: le meurtre de Pélias par Médée (VII, 297-349)", $R P h 63$ (1989) 67-74.

GalinsKY, G.K.: Ovid's Metamorphoses. An Introduction to the Basic Aspects, Oxford/Berkeley/Los Angeles 1975.

(37) Existe a versăo de sua existência imortal na ilha de Léucade, casada com Aquiles. 
GraF, F: "Medea, the Enchantress from Afar", en Clauss-Johnston (1997) 2143.

HaRDIE, Ph.R.: "The speech of Pythagoras in Ovid's Metamorphoses 15: Empedoclean Epos", CQ 45 (1995) 204-214.

HaRdie, Ph.R.; BARCHIESI, A.; HINDS, St. (eds.): Ovidian Transformations: Essays on the 'Metamorphoses' and its reception, Cambridge, Cambridge Philological Society, 1999.

Johnston, S.I.: "Corinthian Medea and the Cult of Hera Akraia", en ClaussJohnston (1997) 44-70.

LAFAYE, G.: Les Métamorphoses d'Ovide et leur modeles grecs, Paris 1904 (reimpr. Hildesheim/New York 1971).

LUDWIG, W.: Struktur und Einheit der Metamorphosen Ovids, Berlin 1965.

MENSCHING, E.: "Carmen perpetuum novum?" Mnemosyne 22 (1969) 165-169.

MYers, K.S.: Ovid's Causes:Cosmogony and Aetiology in the Metamorphoses, Ann Arbor, University of Michigan Press, 1994 (res. St. M. Wheeler, BMCR 95.03.01).

NewlandS, C.: "The Metamorphosis of Ovid's Medea", en Claus-Johnston (1997) 44-69.

OTIS, B.: Ovid as an Epic Poet, Cambridge 1966.

SCHMIDT, E.A.: Ovids Poetische Menschenwelt: Die Metamorphoses als Metapher und Symphonie, Sitzungsbericht der Heidelberger Akademie der Wissenschanften, Phil.-Hist. Klasse, Bericht 2, Heidelberg, Carl Winter Universitätsverlag, 1991 (res. Ch. Segal, BMCR 03.04.12).

SEGAL, Ch.: "'Tantum medicamina possunt': la magie dans les Métamorphoses d'Ovide", en La magie (Actes du Colloque International de Montpellier, 2527 mars 1999), ed. por A. Moreau; J.-C. Turpin, Montpellier, Université Paul Valéry, 2000, vol. III, 45-70.

- "Black and White Magic in Ovid's 'Metamorphoses': Passion, Love, and Art", Arion 3rd. ser. 9 (2001-2002) 1-34.

Solodow, J.B.: The World of Ovid Metamorphoses**, 1988.

Tissol, G.: The face of Nature: Wit, Narrative, and Cosmic Origins in Ovid's Metamorphoses, Princeton, Princeton University Press, 1997 (res. J.B. Solodow, BMCR 00.01.26). 